\title{
Editorial
}

\section{Prof. Dr. Aroldo Miniti - A Great Master}

\author{
Ricardo Ferreira Bento, MD, PhD ${ }^{1}$ \\ ${ }^{1}$ Department of Otorhinolaryngology, Universidade de São Paulo,
School of Medicine, São Paulo, SP, Brazil
}

Int Arch Otorhinolaryngol 2016;20:291-293.

Medicine is truly a unique art and is undoubtedly the synthesis of a triple humanizing and ethical role, translated as personally helping older colleagues perform a therapeutic act and teaching younger ones to do the same.

People who know Professor Aroldo (-Fig. 1) will aver that he was the embodiment of that maxim.

Born on December 29, 1935, in São Paulo, Brazil, he pursued his studies at the Rio Branco de São Paulo College and graduated as a physician from the USP Faculty of Medicine in 1960, undergoing the Otorhinolaryngology residency training at the HCFMUSP.

He defended his doctoral thesis titled "Closure of perforations of the tympanic membrane using dura mater: experimental study in mice," and applied for the position of Associate

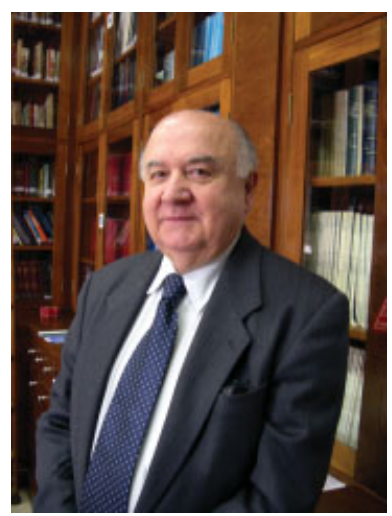

Fig. 1 Prof. Dr. Aroldo Miniti.

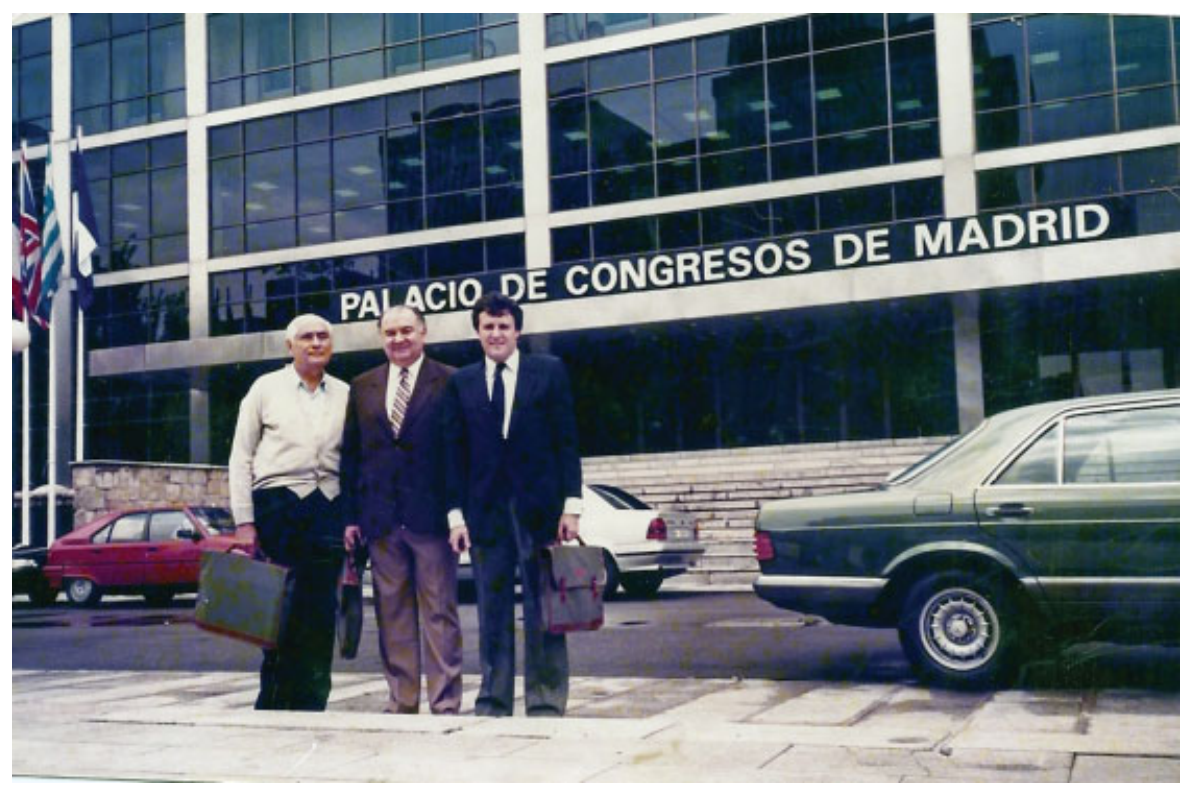

Fig. 2 Prof. Miniti attending one of many congresses along side with Prof. Alexandre Medicis da Silveira and Prof. Ricardo Bento.

Address for correspondence Ricardo Ferreira Bento, MD, PhD, Otorhinolaryngology,

Universidade de São Paulo, Av. Dr.

Enéas de Carvalho Aguiar 255, sala 6167, São Paulo, SP 05403-000, Brazil (e-mail: rbento@gmail.com).
Copyright $\odot 2016$ by Thieme Publicações License terms Ltda, Rio de Janeiro, Brazil

() (1) $\odot \circledast$ 


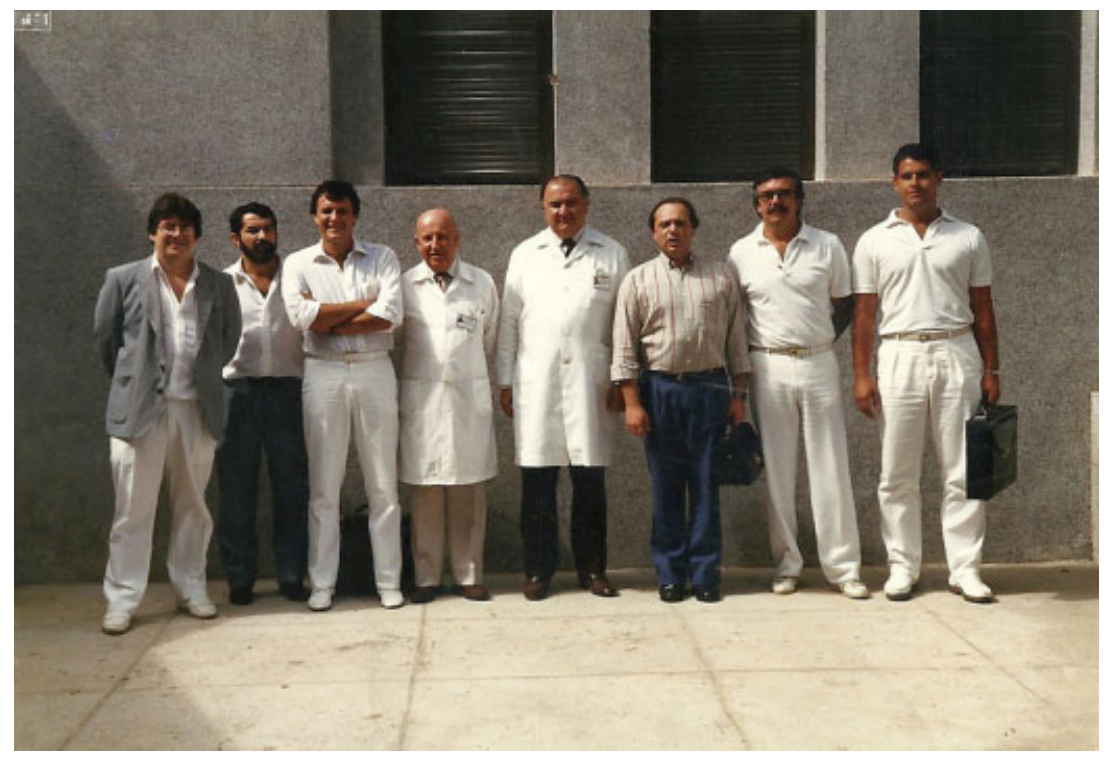

Fig. 3 Prof. Miniti with Prof. Lamartine Paiva, then Chairman Otorhinolaryngology Department and Clinic assistants.

Professor in 1970. ${ }^{1,2}$ He did his internship in Chicago, U.S.A., with David Austin, one of the most notable otologists of the time, wherein he developed techniques that he learned from Professor Correia, his mentor in middle ear surgery.

The technique of using dura mater was practiced for many years in Brazil.

An outstanding ear surgeon, he leaves behind a teaching legacy in HC and in Brazil, after teaching hundreds of surgeons not only the art of medicine but, most importantly, the ethical and moral principles of the profession.

He chaired numerous conferences and always participated spiritedly in all events and congresses in Brazil (-Fig. 2).
A disciplinarian, but with a big heart, Professor Aroldo was revered by the medical residents and assistants and held in high esteem by otorhinolaryngologists from across the country.

Despite his generosity, he always imposed strict discipline at the workplace, but strived to ease differences and maintain harmony in the Clinic.

He treated everyone equally, from the humblest to the most important, and was generous toward all those seeking his help (-Fig. 3).

Professor Aroldo Miniti was the person who initiated the modernization of the ORL clinic of the FMUSP and of our specialty in Brazil. The unique aspect of this clinic was to

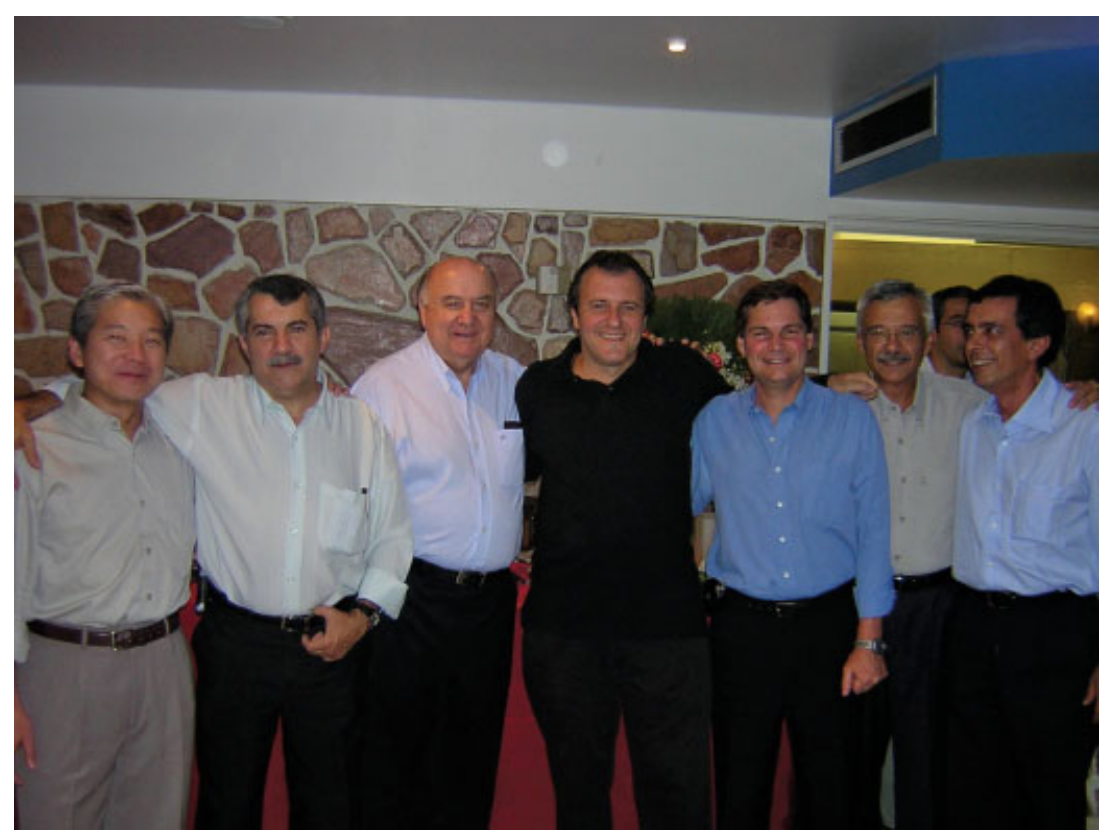

Fig. 4 Prof. Miniti in 2005 with colleagues. From left to right: Domingos Tsuji, Perboyre Sampaio, Aroldo Miniti, Ricardo Bento, Luiz Ubirajara Sennes, Silvio Antonio Marone, Ivan Miziara. 


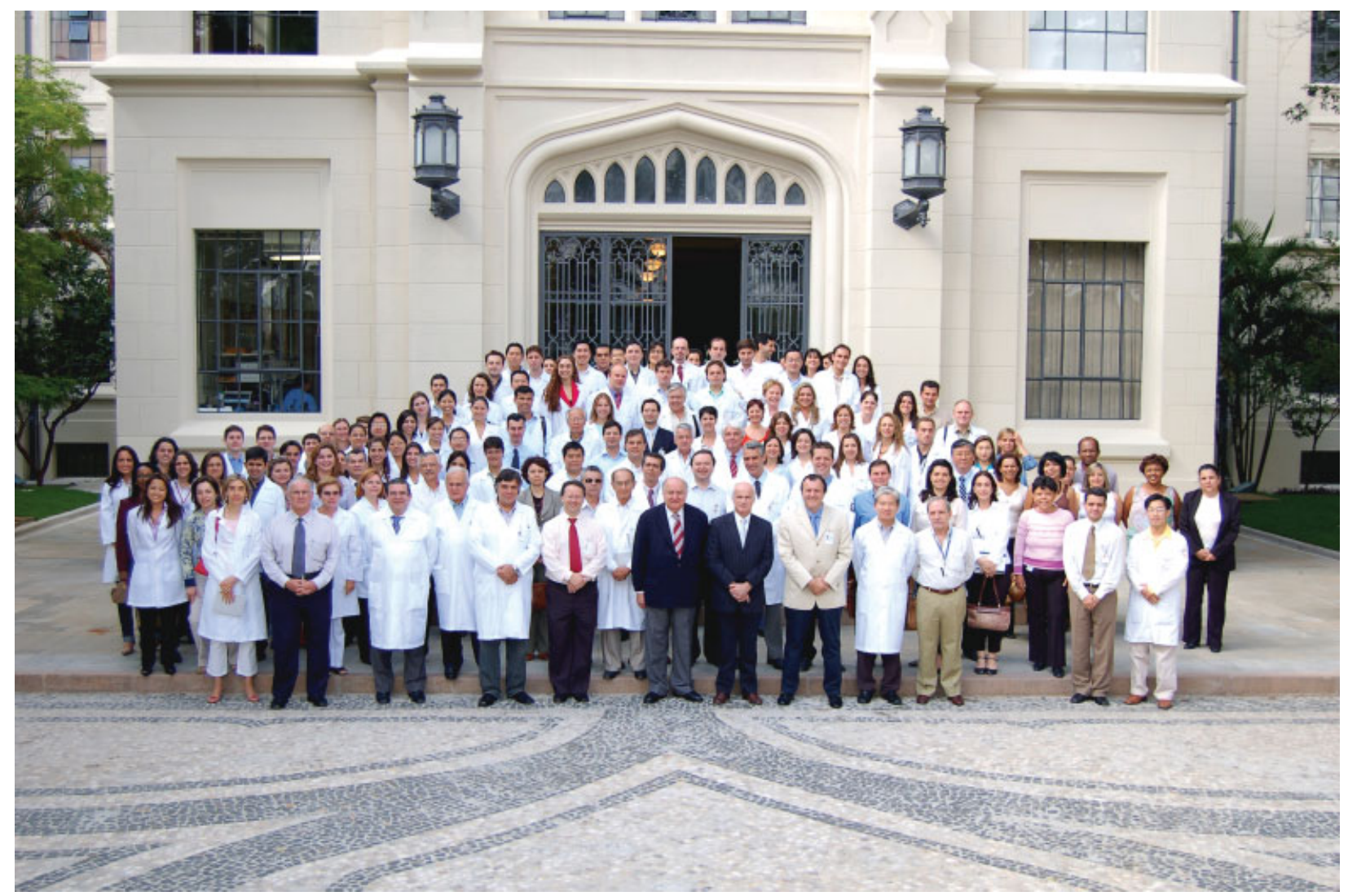

Fig. 5 Staff of ENT Department in December 2006.

encourage formation of groups of various specialty areas, which were then expanding, and give them the freedom to perform. This helped create a generation of great names who are today opinion leaders in their fields (- Fig. 4).

Having performed the first ear homograft, he would always say that the ORL was once again a pioneer in that it was the first specialty to perform an "organ transplant," which came into practice only much later in other specialties such as kidney and heart transplants, among others. He said that the Clinical Hospital had built an Institute (INCOR - Heart Institute) for the first heart transplant in Brazil not knowing that the ORL had already performed transplants many years previously!

Otorhinolaryngology was experiencing a golden moment with the expansion of its areas of action beyond the classic ear, nose, and throat to sleep medicine, facial plastic surgery, facial nerve diseases, and electrophysiology and modern otoneurology. With these developments, the ORL was no longer treated as the hospital "basement," looked down upon by other specialties as a "minor" field, and began to gain status. This was a worldwide phenomenon. In the career history book of Dr. William House, one of the main, if not the main, otologists of the $20^{\text {th }}$ century, states that in choosing this specialty, he was criticized by his colleagues and professors who said, "You are doing ORL? It's a sub-area and its only purpose is to remove tonsils! Choose something else." There were even unfilled vacancies for ORL residencies in the 1950s.

In such a context, Professor Aroldo proved his worth by initiating the development of the sub-areas of the specialty and, with that, there were many among his assistants who gained experience abroad and later developed their respective groups.

Professor Aroldo was one of the founders of the International Archives of Otorhinolaryngology and was part of its Editorial Board for several years.

He retired from his academic career in 2006, and I had the privilege and the difficult job of succeeding him; in every decision, until this day, I still think of his teachings (-Fig. 5).

Sadly, Professor Aroldo, our dear master, is no longer with us today and his journey has ended. More important than the sadness of this moment is the knowledge that the path he showed us still bears the fruits, wisdom, and teachings of his life. We are glad that he was able to fulfill his mission among us and are certain that wherever he is, he is looking after his friends and disciples who are following his footsteps.

Professor Aroldo, thank you for everything!

"To teach is to learn twice."

\section{References}

1 Miniti A. Fechamento de perfurações da membrana do tímpano com dura-máter: estudo experimental em ratos [thesis]. Universidade de São Paulo; São Paulo, Brazil; 1969

2 Miniti A. Estudo das concentrações de doxiciclina e estearato de eritromicina na secreção do seio maxilar de doentes portadores de sinusite maxilar crônica [thesis]. Universidade de São Paulo; São Paulo, Brazil; 1970 